\title{
History of Epidemics and COVID-19
}

\section{Salgınlar Tarihçesi ve COViD-19}

\author{
iD Pelin YÜKSEL MAYDA, iD Harika Öykü DİNÇ
}

Bezmialem Vakıf University Faculty of Pharmacy, Department of Pharmaceutical Microbiology, İstanbul, Turkey

\begin{abstract}
In archaeological excavations, it has been reported that formations resembling bacterial fossils are found among the rock layers and they belong to millions of years ago. There are those who have created the flora and preserved us by creating our flora, and those that have brought us to the end, as well as those that help us to form the microorganisms that we share with the same planet, whose existence dates back to ancient times. Although our immune system and medical facilities are trump cards against microorganisms living in the world for much longer than human beings, these are not always enough to protect us, and microorganisms are causing outbreaks that will make history. In this review, we aimed to examine the epidemic diseases experienced by human beings from past to present and their effects.
\end{abstract}

Keywords: Epidemic, pandemic, COVID-19

\section{ÖZ}

Yapılan arkeolojik kazılarda, kaya tabakaları arasında bakteri fosillerine benzeyen oluşumlara rastlandığı ve bunların milyonlarca yıl öncesine ait olduğu bildirilmiştir. Varlıkları bu kadar eski zamanlara dayanan aynı gezegeni paylaştı̆̆ımız mikroorganizmaların aralarında yediklerimizin oluşmasını sağlayanlar ve floramızı oluşturarak bizi koruyanlar olduğu gibi sonumuzu getirebilecek olanlar da var. İnsanoğlundan çok daha uzun süredir dünyada yaşayan mikroorganizmalara karşs her ne kadar bağışıklık sistemimiz ve tıbbi imkanlar, elimizdeki kozlar olsa da bunlar bizi korumaya her zaman yetmiyor ve mikroorganizmalar tarihe damga vuracak salgınlara neden olarak karşımıza çıkıyor. Bu derlemede geçmişten günümüze insanoğlunun yaşadığı salgın hastalıkları ve etkilerini irdelemeyi amaçladık.

Anahtar Sözcükler: Salgın, pandemi, COVİD-19

\section{Introduction}

Epidemics, defined as an increase in the number of individuals infected with an infectious disease in a certain population and in a certain time period, have always been a problem due to microorganisms for a long time (1). Sometimes these epidemics caused many deaths that would cause a high number of deaths, sometimes famines that would lead to other diseases, and sometimes political events that could even stop wars (2). Throughout the history, these microorganism-induced epidemics are mostly caused by bacteria and viruses, as well as also people and, also animals, carry and spread them (3). When we look at diseases transmitted by animals, it was possible that hunter-gatherer people started agriculture and settled down and at the same time, microorganisms in these animals could be transmitted to humans from animal products (milk, feces, etc.) by domestication of animals. In addition to the contamination caused because of these products, the mutations in viruses and the resistance developed by bacteria also played a role in the epidemics to create greater problems (4).

\section{Epidemics Effecting Human History from Ancient Times to the Present}

In $430 \mathrm{BC}$, The Athens plague, which was seen during the Peloponnesian War between Athens and Sparta, and lasted for 
five years and caused the death of 100 thousand people, was recorded as the first pandemic in the ancient times in human history. Libya, Ethiopia, Egypt are the countries affected by Athens plague. Fever, thirst, skin rash and lesions were also detected with the disease and various descriptions like typhoid and Rift valley fever have been made. It is considered that the overpopulation caused by the war was effective in the spread of this first pandemic (5).

In the years 165-180 AC, another epidemic disease, although the cause is still unclear, Antoninus plague, experienced in the Roman Empire and considered to be brought by the soldiers returning from eastern expeditions, was accompanied by the symptoms such as fever, sore throat, diarrhea, and rash, even if it reminds diseases such as smallpox and measles. This epidemic is named after the Roman emperor Marcus Aurelius Antoninus died, and is believed as one of the major plague epidemics, killed 2 thousand people a day and lost 30 percent $(5$ million) of the total population of the empire. This epidemic started a process that continued until the destruction of the empire, as the power loss of the empire, and led to power wars and civil wars within the empire $(6,7)$.

In 250-270 AC, Cyprian Plague of the Cyprian, named by the Bishop of Carthage, caused the loss of 1 million of the world population, which was approximately 200 million at that time. The epidemic first started in Ethiopia, than spread to Rome, Greece and Syria, and lasted about 20 years. Diarrhea, vomiting, throat ulcers, fever, lesions on the hands and feet, were some of the symptoms of the plague and the pandemic continued to be seen repeatedly in the following 3 centuries (8).

The plague of Justinian was thought to be caused by the bacterium Pasteurella pestie (later named Yersinia Pestis), which started in Europe in 541 and spread to Egypt, Palestine, Syria and from there to Anatolia. This pandemic is thought to have entered the city through mice, which were among the supplies brought into the city by military units. It was thought that the people was infected by the plague which is transferred to humans by the biting of a flying insect named "Xenopsylla" living on mice and caused the infected people to die within a few days. This was interpreted as the first emergence of the bubonic plague, nearly a few hundred daily deaths at the beginning, which was sooner reached to thousands of daily deaths. The disease continued its normal course and disappeared by itself, but 25 to 100 million people were lost till that date ( $26 \%$ of the world's population) (9).

The Japanese Smallpox Outbreak, which occurred in Tokyo between 735-737, spread to neighboring countries, causing the death of approximately one million people. Most of those who died in the epidemic that killed a third of the Japanese population were children (10).

The black plague epidemic, caused by the bacterium Yersinia pestis, which led to one of the most devastating epidemics in history, killed between 75 and 200 million people, one third of the world's population, between 1346 and 1353. After the deaths, the Black Plague epidemic, which caused the God and the church to be questioned in the society, was effective enough to cause a reform in religion (11). Climate change and hot and dry winds facilitated the transport of bacteria by fleas. In addition, the bacteria were spreading to the port cities by the fleas living on the mice on the ships. The beginning of the use of masks began with the theory that doctors suppressed the smell with 55 spices and dried flowers due to the miasma theory. Apart from that, the concept of quarantine was first reported in 1,377 with the enactment of a law that ships and commercial caravans, that want to enter into Ragusa (Croatia-Dubrovnik), coming from places where plague was seen, cannot enter after 1 month disinfection in Mrkan island or Cavtat town (12). "Quarantine", which means 40 days in Italian, has a symbolic and religious meaning, as well as due to the infections that will occur after the puerperium. For the first time in the history of the Ottoman Empire, the official quarantine decision was taken in 1838 and the Ministry of Quarantine was established in 1839 to institutionalize this situation. Urla quarantine island was built together with the French in the $18^{\text {th }}$ century as the first quarantine application area (13).

Europeans who came into contact with the natives of the Americas in the $15^{\text {th }}$ century, infected the microorganisms to the people here. Chickenpox, which killed one third of Europe, killed millions of Native Americans whose immune systems did not recognize this factor. By the $19^{\text {th }}$ century, one in two Native Americans died of diseases derived from Europe (14).

In the $16^{\text {th }}$ century, the epidemic disaster caused by the occurrence of several different diseases such as smallpox ("Cocoliztli" in Aztec) measles and diphtheria, which was carried here by the Spanish from Europe in Mexico, is referred to as "cocoliztli outbreaks". Cocoliztli outbreaks occurred 3 times between 1520 and 1576. Today, it is estimated that the outbreaks claimed to be caused by salmonella bacteria killed nearly 25 million people. This epidemic is thought to have spread from Mexico, from Venezuela to Canada. When the World Health Organization (WHO) launched a campaign for the eradication of smallpox in 1967, it was estimated that there were 10-15 million smallpox cases and 2 million deaths in the world that year. The last case was reported in Somalia in 1977. Smallpox was declared to eradicate in 1980 (15-17).

There have been seven major cholera outbreaks in our history, but the deadliest of these was the third cholera epidemic that occurred between 1852-1860. The main cause of cholera was human feces-contaminated drinking water, but it was understood in the third epidemic. After that, the importance of the boiling of drinking water was suggested. India, where the Ganges river, one of the dirtiest rivers in the world, has been the most affected country. The epidemic spread from India to Afghanistan, Russia, from there to Europe and Africa, and finally to America. The seven cholera epidemics, in which millions of people died, were seen as severe diarrhea $(18,19)$.

After the Justinian Plague and the Black Plague, the Third Plague epidemic, which occurred in 1855-1859, whose origin 
was the Chinese Yunnan province, caused the death of more than 12 million people all over the world. The epidemic, whose effects have continued for a century, was carried to the American continent by rats from the far east. At that time, scientists not only found the factors of diseases, but also began to be successful in drug treatments (20). As a result of a visit to Australia after Fiji passed to the British Empire, they brought the disease back to their islands and in 1875, 40 thousand people of whom was the $1 / 3$ of the Fiji population, were lost in the Fiji Measles pandemic (21).

During the First World War between 1914-1918, the typhus epidemic caused by lice carrying typhus bacteria also caused 25 million people in Europe and Asia to become ill, and nearly 3 million people died especially in the Soviet Union countries. While Western countries took precautions against lice and protected themselves, it was seen that many people lost their lives because the Eastern countries failed to do so $(22,23)$.

The Russian flu, which started in 1889 and spread rapidly all over the world, killed 1 million people. It spread from Russia to Europe, from there to America, Australia and Africa. The most important factor in the spread of the epidemic was the railways between Europe and Russia (24). By 1918, the Spanish Flu epidemic caused by the H1N1 influenza virus, which would continue for two years, infected 500 million people in the years following the First World War, causing the death of 50 to 100 million people. The data obtained showed that this number is much more than the number of people who died in war. Although many countries were affected, the most casualties were in India with approximately 18 million deaths. Young age groups were the most affected group in this epidemic. This epidemic, which has affected the whole world, brought to mind today's measures with features such as the use of masks, gargling with salt water and drawing attention to vitamin $\mathrm{C}$ consumption. In addition, this epidemic created the need for an international fight against diseases affecting the whole world, and in 1919, today's WHO was established in Vienna, Austria (25-28).

Flu caused by influenza virus (H2N2) appears again as the Asian flu in 1957. Nearly 4 million people died in Asian Flu, which was first seen in Singapore and is estimated to be transmitted to humans by mutation in ducks. The epidemic was stopped with the vaccine found, and within the ten-year Asian flu disappeared in 1968. Asian Flu located in history as one of the most important examples demonstrating the importance and the effect of vaccination $(26,29)$. The cause of the Hong Kong Flu, which killed 1 million people in 1968, was identified as the $\mathrm{H} 3 \mathrm{~N} 2$ type of Influenza A virus. Babies and the elderly were the most affected by this epidemic, which is a contagious respiratory disease (30).

In the middle of the $20^{\text {th }}$ century, human immunodefiency virus (HIV), which attacks the immune system, especially CD4 T-cells, passed from monkeys to humans, was first seen in Congo in 1959; however, the definitive diagnosis was made in the 1980s (31). According to the United Nations Joint Program on HIV/AIDS (UNAIDS) 2019 report; Since the beginning of the HIV epidemic in the world, 74.9 million people have been infected with HIV, and 32 million have died from AIDS-related diseases (32). This epidemic spreading by blood and sexually, which was stigmatized due to the fact that the first cases were homosexual, was brought under control after the discovery of effective antivirals. With strong protection programs and raising public awareness was also effective in bringing it under control. Although it was in the status of fatal diseases when the first epidemic broke out, it is now in the status of chronic diseases that can be controlled with lifelong drug therapy. Although effective vaccine studies continue to date, no effective vaccine has yet been found $(33,34)$.

The H1N1 Swine Flu epidemic, which started to spread in April 2009, was first seen in Mexico and spread to America and later to 212 countries. WHO announced the start of the pandemic on June 11, 2009. Most deaths from this outbreak occurred in Africa and Southeast Asia. WHO announced that approximately 284 thousand people died and ended on 10 August 2010. The effective antivirals and vaccines take place in ending the epidemic quickly (35).

Until the 2000s, coronaviruses (HCoV-229 E, HCoV-O43, HCoV-NL63, HKU1-CoV) were generally known as the agents that cause upper respiratory tract infections in children (36). In the 2000s, it started to be a problem and cause epidemics as zoonoses. The first serious coronavirus outbreak was the SARS$\mathrm{CoV}$ that started in China in 2002, thought to be caused by bats. The one-year epidemic spread to 29 countries, with 8,096 infected people and 774 deaths. The most striking aspect of this epidemic was early warning. WHO became aware of it in March 2003, and the epidemic stopped in July 2003 (37,38). By 2012, another coronavirus outbreak, MERS-CoV, started in Saudi Arabia. The factor, which was found to be transmitted to humans through bats and camels, spread to 27 countries. It was detected in 2,494 patients and 858 of these patients died. Although it is rarely seen today, cases still continue. Although these two coronaviruses have been brought under control, effective antivirals and vaccines have not yet been found $(39,40)$.

By 2019, it is estimated that coronaviruses reappear as a new type of coronavirus in Wuhan, China, in November, when the incubation period was taken into account. After the incubation period, following the first case of atypical pneumonia on 11 December 2019, 3 more cases were admitted to the hospitals on 17 December 2019. On December 31, 2019, 27 cases of atypical pneumonia reported, most of them working at a seafood and livestock market in Wuhan. As a result of examining the samples taken from the patients, on January 7, it was understood that the virus causing the disease was from the beta coronavirus family, and the virus was named as new coronavirus-2019 (nCoV-2019) (41). It has been reported that the $\mathrm{nCoV}-2019$ genome is $70 \%$ similar to the SARS-CoV The $\mathrm{nCoV}$ has been officially named as SARS$\mathrm{CoV}-2$, and the name of the disease it causes has been designated COVID-19 (42,43). Cases have been reported in 216 countries around the world. As of June 2020, more than 10 million 
cases and over 500 thousand deaths have been reported. In our country, cases are exceeded 200 thousand and the deaths are over 5,000 (44).

\section{Result}

We must always be wary of microorganisms with which we share the world, whose history is older than us. When we look at our past, we see that they cause epidemics with many losses. Each epidemic lead human to new searches and prepares the next with the measures taken. New searches involving drug and vaccine studies sometimes result in positive results, such as the elimination of smallpox with vaccination, and sometimes negative results, like HIV, which takes years and still cannot be obtained from vaccination studies. While these searches continue, sometimes the microorganism loses its virulence and ends the epidemic itself, and sometimes they have resistance against the effective treatment developed, or the microorganism mutates. Regardless of the condition, as long as human beings live, it is as clear as the day that they will come face to face with these microorganisms, and the thing to do is to know the principles of protection from infectious diseases. We see that the ways of protection have not changed much from İbn-i Sina's "El Kanun fi't Tib" book to today. These recommendations consist of personal hygiene, distance and stress-free life.

Peer-review: Externally peer-reviewed.

\section{Authorship Contributions}

Concept: P.Y.M., H.Ö.D., Design: P.Y.M., H.Ö.D., Data collecting or Processing: H.Ö.D., Analysis or Interpretation: P.Y.M., Literature Search: P.Y.M., H.Ö.D., Writing: P.Y.M.

Conflict of Interest: No conflict of interest was declared by the authors.

Financial Disclosure: The authors declared that this study received no financial support.

\section{References}

1. Hacımustafaoğlu M. Enfeksiyon Hastalıklarında Pratiğinde Salgın Tanımlanması. J Pediatr Inf 2018;12:172-3.

2. Gürel Z, Aslan D. Halk sağlığı bakış açısıyla gıda kaynaklı krizler ve önleme yaklaşımları. Turk Hij Den Biyol Derg 2019;76:361-76.

3. Ergönül Ö. Epidemiology is a field that searchs diseases and their indicators. Eur Arch Med Res. 2016;32:1-7.

4. Kılınç, GM, Omrak A, Özer F, Günther T, Büyükkarakaya AM, Bıçakçı E, et al. The demographic development of the first farmers in Anatolia. Curr Biol 2016;26:2659-66.

5. Littman, RJ. The plague of Athens: epidemiology and paleopathology. Mt Sinai J Med 2009;76:456-67.

6. See Y, Furuse A, Oshitani SH. Origin of the measles virus: divergence from rinderpest virus between the 11th and 12th centuries. Virol J 2010;7:52.

7. Littman RJ, Littman ML. Galen and the Antonine plague. Am J Philol 1974;94:243-55.
8. Daniel R. Bu Kutsal Tohum: Kuzey Afrika Erken Kiliseleri İnanç, Umut ve Sevgi, (Chester, Ilgın Yayınları, 2010: www.opaltrust.org) Kaynak bulunamadi.

9. The Plague of Justinian. History Magazine. 2009;11:9-12. Bir tek wikipedide bu şekliyle geçiyordu

10. Hurd M. History of epidemics and pandemics, Salem Press Encyclopedia of Health, 2020.

11. Black Death's Gene Code Cracked. Wired. Last Accessed Date: 30.06.2020. Available from.: https://web.archive.org/ web/20150426160438/http:/archive.wired.com/medtech/health/ news/2001/10/47288

12. Mackowiak PA, Sehdev PS. The Origin of Quarantine. Clinical Infectious Diseases 2002;35:1071-2.

13. Anadolu'nun sağlık kapısı: Urla Tahaffuzhanesi. Erişim Tarihi: 30.06.2020. URL: https://www.aa.com.tr/tr/kultur-sanat/ anadolunun-saglik-kapisi-urla-tahaffuzhanesi/1783898

14. Dalia V. Koronavirüs: Karantina nedir, hangi hastalıklar için uygulandı? BBC News-Türkçe, BBC Mundo, Erişim Tarihi: 30.06.2020. URL: https://www.bbc.com/turkce/haberler-dunya-51630138

15. Acuna-Soto R, Stahle DW, Therrell MD, Griffin RD, Cleaveland MK. When half of the population died: the epidemic of hemorrhagic fevers of 1576 in Mexico. FEMS Microbiol Lett 2004;240:1-5

16. Marr JS, Kiracofe JB. Was the Huey Cocoliztli a hemorrhagic fever? Med Hist 2000;44:341-62.

17. Brmen JG, Arıta I, Fenner F. Preventing the return of smallpox. N Engl J Med 2002;348:463-6.

18. Dunnigan M. Commentary: John Snow and alum-induced rickets from adulterated London bread: an overlooked contribution to metabolic bone disease. Int J Epidemiol 2003;32:340-1.

19. Waldman R, Claeson M. Cholera. Encyclopedia Britannica. Last Accessed Date: 09.08.2019. Available from: https://www.britannica. $\mathrm{com} /$ science/cholera

20. Bramanti B, Stenseth NC, Walløe L, Lei X. Plague: a disease which changed the path of human civilization. Adv Exp Med Biol 2016;918:1-26.

21. Ofcansky TP. British colonial administration in the Fiji Islands during the 1875 measles epidemic. Adler Mus Bull 1984;10:23-7.

22. Bechah Y, Capo C, Mege J-L, Raoult D. Epidemic typhus. Lancet Infect Dis 2008;8:417-26.

23. Raoult D, Woodward T, Dumler JS. The history of epidemic typhus. Infect Dis Clin N Am 2004;18:127-40.

24. Gregg MB, Hinman AR, Craven RB. The Russian flu, its history and implications for this year's influenza season. JAMA. 1978;240:22603

25. Brundage JF, Shanks GD. What really happened during the 1918 influenza pandemic? The importance of bacterial secondary infections. J Infect Dis 2007;196:1717-8

26. Yang W, Petkova E, Shaman. The 1918 influenza pandemic in New York City: age-specific timing, mortality, and transmission dynamics. Influenza Other Respir Viruses. 2014;8:177-88.

27. Arnold D. Dearth and the modern empire: the 1918-19 influenza epidemic in India. Trans R Hist Soc 2019;29:181-200. 
28. WHO. WHO issues best practices for naming new human infectious diseases. Last Accesed Date: 08.04.2020. Available from: https:// www.who.int/news/item/08-05-2015-who-issues-best-practices-fornaming-new-human-infectious-disease. 8 May 2015.

29. Claire J. History lessons: the Asian Flu pandemic. Br J Gen Pract 2009;59:622-3.

30. Charles CW. Origin and progress of the 1968-69 Hong Kong influenza epidemic. Bull World Health Organ 1969;41:343-8.

31. Cohen O, Cicala C, Vaccarezza V, Fauci AS. The immunology of human immunodeficiency virus infection. In: Mandel GL, Douglas RG, Bennett JE (eds). Principles and Practice of Infectious Diseases. 5th edition. Philadelphia: Saunders: 2000; 107:1374-98.

32. T.C. Sağlık Bakanlığı, Halk Sağlığı Genel Müdürlüğü. Last Accessed Date: 30.06.2020 Avaialeble from: https://hsgm.saglik.gov.tr/tr/ haberler/1-aralik-dunya-aids-gunu.html

33. Dökmetaş İ, Hamidi AA. HIV epidemiyoloji. Türkiye Klinikleri J Inf Dis-Special Topics 2016;9:6-11.

34. Haroz D, Zinkernagel DW, Kiragu K. Development and Impact of the Global Plan. Acquir Immune Defic Syndr. J Acquir Immune Defic Syndr 2017;75(Suppl 1):S2-6.

35. Chowell G, Viboud C, Wang X, Bertozzi SM, Miller MA. Adaptive vaccination strategies to mitigate pandemic influenza: Mexico as a case study. PLoS One 2009; 4:e8164. PMID:19997603.
36. XinyiLY, LingY,James T, Xiang LD. Human coronaviruses: a review of virus-host interactions. Diseases 2016;4:26.

37. Peiris JSM, Phil D, Yuen KY, Osterhaus ADME, Stöhr K. The Severe acute respiratory syndrome. N Engl J Med 2003;349:2431-41.

38. Low DE, McGeer A. SARS-One year later. $\mathrm{N}$ engl J Med 2003;349:2381-82.

39. T.C. Sağlık Bakanlığı, Halk Sağlığı Genel Müdürlüğü. Last Accessed Date: 30.06.2020 Avaialeble from: https://hsgm.saglik.gov.tr/tr/ bulasici-hastaliklar/mers-co-v/mers-cov-liste/mers-co-v.html

40. İnal S. Middle East Respiratory Syndrome-Coronavirus (MERSCoV) Enfeksiyonu. Okmeydanı Tip Derg 2016;32(Ek sayı):37-45.

41. Li Q, Guan X, Wu P, Wang X, Zhou L, Tong Y, et al. Early Transmission Dynamics in Wuhan, China, of Novel CoronavirusInfected Pneumonia. N Engl J Med 2020;382:1199-207.

42. Bennett J, Dolin R, Blaser MJ. Mandell, Douglas, and Bennett's Principles and Practice of Infectious Diseases. 8th ed. Philadelphia, PA: Elsevier/Saunders; 2014.

43. T. C. Sağlık Bakanlığı. 2019-nCoV Hastalığı Sağlık Çalışanları Rehberi. 2020. Available from: https:/hsgm.saglik.gov.tr/depo/ haberler/ncov/2019-nCov_Hastal_Salk_alanlar_Rehberi.pdf

44. Johns Hopkins University\&Medicine. COVID-19 Dashboard by the Center for Systems Science and Engineering (CSSE) at Johns Hopkins University. Last Accessed Date: 30.06.2020 Avaialable from: https://coronavirus.jhu.edu/map.html 